\title{
Original
}

\section{The Roles of Fat-Storing Cells and TGF $\beta$ Polypeptides in Periductular Fibrosis in Fulminant Hepatitis}

\author{
Tsutomu Mizota ${ }^{1)}$, Toshiaki Kunimura ${ }^{2)}$, Takako Sugisawa ${ }^{2)}$, \\ Kouji S AITOU $^{2)}$, Masahiro $\mathrm{W}_{\mathrm{ADA}^{2}}{ }^{2)}$, Motohiro KoJIMA ${ }^{2)}$, \\ Keiko Henmi ${ }^{2}$, Seichi Tobinaga ${ }^{1)}$, Hideyo ITAKura ${ }^{3)}$ \\ and Toshio Morohoshi ${ }^{2}$
}

\begin{abstract}
The present study examines the roles of fat-storing cells and TGF $\beta$ in the process of ongoing periductular fibrosis that occurs during the course of fulminant hepatitis. Hepatic specimens were obtained at autopsy from 23 patients with fulminant hepatitis. Immunohistochemistry was performed using antibodies to alpha smooth muscle actin ( $\alpha$ SMA), proliferating cell nuclear antigen (PCNA), and transforming growth factor beta (TGF $\beta$ ) 1 and 2 . Seven cases were examined by electron microscopy to identify the fibrogenic cells surrounding the bile ductules. The proliferated bile ductules were surrounded by spindle shaped mesenchymal cells showing positive immunoreactivity for cytoplasmic $\alpha$ SMA and nuclear PCNA, and the extent of periductular fibrosis was correlated with the time course of the disease. Electron microscopy confirmed these cells as fat-storing cells. Ductular epithelia maintained positive immunoreactivity for TGF $\beta 1$ and 2 throughout the course of the disease, macrophages were positive for TGF $\beta$ only in the earlier phase and fat-storing cells were positive in the latter phase of the disease. The process of periductular fibrosis that occurs during fulminant hepatitis is proposed to occur as follows: firstly, bile ductular proliferation appears as a reaction to massive hepatic necrosis: secondly; TGF $\beta 1$ and 2 expressions in ductular epithelia and TGF $\beta 1$ expression in macrophages promote the aggregation and fibrogenesis of fat-storing cells around the periductular areas; and finally, TGF $\beta 1$ expression in the fat-storing cell itself additionally promotes an ongoing periductular fibrosis.
\end{abstract}

Key words : fulminant hepatitis, periductular fibrosis, fat-storing cells, TGF $\beta$

\section{Introduction}

Fat-storing cells are found in the space of Disse in normal human liver, and play an active role in hepatic fibrosis, which occurs in various acute and chronic hepatic diseases ${ }^{1}$. Recently, fat-storing cells were implicated in periductal fibrosis occuring in biliary hepatitis ${ }^{2}$. It is known that fat-storing cells also play a central role in postnecrotic hepatic fibrosis ${ }^{3)}$.

1) Department of Social and Environmental Medicine, Institute of Tropical Medicine, Nagasaki University, 1-12 Sakamoto Nagasaki 851-8523, Japan.

2) First Department of Pathology, Showa University School of Medicine.

3) Department of Pathology, Institute of Tropical Medicine, Nagasaki University. 
Despite this data, it remains unclear whether these cells are involved in the process of periductular fibrosis occurring in fulminant hepatitis. Various cytokines such as transforming growth factor beta (TGF $\beta$ ) and platelet-derived growth factor (PDGF) are also involved in the pathogenesis of hepatic fibrosis ${ }^{4,5}$. These fibrogenic growth factors released by inflammatory cells promote the proliferation of fat-storing cells ${ }^{6,7)}$. Furthermore, recent studies describe the secretion of TGF $\beta$ polypeptides and PDGF into the bile duct or proliferated ductular epithelia during chronic liver disease and biliary atresia ${ }^{8-10}$.

This study sought to clarify the roles of fat-storing cells and TGF $\beta$ in the process of ongoing periductular fibrosis during fulminant hepatitis, with particular emphasis on the time course of the disease. We used immunohistochemistry and electron microscopy to correlate fat-storing cells with periductular fibrosis and with the expression of TGF $\beta$, in liver samples from patients with fulminant hepatitis.

\section{Materials and Methods}

\section{Tissue samples}

Hepatic specimens were obtained at autopsy from 23 patients (including ten males and thirteen females) with fulminant hepatitis with a postmortem interval of 2 to 12 hours. All cases were clinically diagnosed as fulminant hepatitis, and the cause of death was hepatic failure in all cases. Hepatitis B virus infection was observed in four cases, but the presence of hepatitis $\mathrm{C}$ virus infection could not be determined as all but two cases had died prior to 1990. Alcoholic or drug-induced hepatitis was clinically excluded. Survival periods from the onset of disease ranged from 3 to 100 days, and the patient ages ranged from 0 to 71 years (Table 1). Normal hepatic tissues obtained at autopsy from 3 patients with no hepatic disease were used as controls. All tissues were fixed in $10 \%$ formalin and embedded in paraffin wax for sectioning and hematoxylin-eosin (HE) staining.

\section{Immunohistochemistry}

Paraffin sections ( $3 \mathrm{~mm}$ thick) were dewaxed in xylene and rehydrated through a graded alcohol series. After reducing the endogenous peroxidase activity with absolute methanol containing $3 \% \mathrm{H} 2 \mathrm{O} 2$, sections were stained using the labeled streptavidin-biotin (LSAB) peroxidase complex technique (K0675, DAKO, Kyoto, Japan). Primary antibodies against alpha smooth muscle actin ( $\alpha$ SMA, 1A4, diluted 1:50; DAKO, Kyoto, Japan), proliferating cell nuclear antigen (PCNA, PC10, diluted $1: 100$, NOVOCASTRA, Newcastle, UK), transforming growth factor beta1 (TGF $\beta$, SC146, diluted 1:50, Santa Cruz, California, USA) and transforming growth factor beta2 (TGF $\beta 2$, SC90, diluted 1:50, Santa Cruz, California, USA) were applied for 18 hours at $4{ }^{\circ} \mathrm{C}$ The immunostaining was visualised using benzidine then lightly couterstained with hematoxylin and examined by brightfield microscopy. Sections were double stained for $\alpha$ SMA using the LSAB alkaline phosphatase complex technique (K0682, DAKO, Kyoto, Japan) and PCNA using the LSAB peroxidase complex technique to identify the proliferative potential of the $\alpha$ SMA positive cells.

\section{Electron microscopy}

Hepatic specimens from 7 patients with fulminant hepatitis $(6,9,10,26,27,37$, and 75 days, respectively, from the onset) were fixed in $2.5 \%$ glutaraldehyde in $0.05 \mathrm{~mol} / \mathrm{L}$ 
Table 1. Clinical findings of the cases

\begin{tabular}{|c|c|c|c|c|c|c|}
\hline case & age & $\operatorname{sex}$ & T-bil $(\mathrm{mg} / \mathrm{dl})$ & PT (\%) & virus & course (days) \\
\hline 1 & 68 & $\mathbf{M}$ & uncertain & uncertain & nAnB & 3 \\
\hline 2 & 36 & $\mathbf{M}$ & 5.9 & 5 & nAnB & 5 \\
\hline 3 & 67 & $F$ & 6.0 & 8 & B & 6 \\
\hline 4 & 71 & $F$ & 10.0 & uncertain & B & 7 \\
\hline 5 & 5 & $\mathbf{M}$ & 12.7 & 8 & nAnB & 7 \\
\hline 6 & 25 & $\mathbf{F}$ & 4.1 & 11 & $\mathrm{nAnB}$ & 9 \\
\hline 7 & 60 & $\mathbf{F}$ & uncertain & 36 & $\mathrm{nAnB}$ & 9 \\
\hline 8 & 0 & F & 13.9 & 3 & B & 9 \\
\hline 9 & 70 & $F$ & 29.0 & 1 & $\mathrm{nAnBnC}$ & 10 \\
\hline 10 & 20 & $\mathrm{~F}$ & 10.2 & 20.7 & B & 10 \\
\hline 11 & 45 & $\mathrm{~F}$ & 12.8 & 11.6 & nAnB & 10 \\
\hline 12 & 45 & $\mathbf{M}$ & 29.1 & 16 & nAnB & 18 \\
\hline 13 & 39 & $\mathrm{~F}$ & 31.0 & 11 & $\mathrm{nAnB}$ & 20 \\
\hline 14 & 0 & $\mathbf{M}$ & 21.0 & 6.2 & $\mathrm{nAnB}$ & 26 \\
\hline 15 & 1 & $\mathbf{M}$ & 17.0 & 21 & nAnB & 27 \\
\hline 16 & 45 & $\mathbf{M}$ & uncertain & 8 & nAnB & 30 \\
\hline 17 & 6 & $\mathbf{M}$ & 33.9 & 23.9 & nAnB & 37 \\
\hline 18 & 48 & $\mathrm{~F}$ & 18.7 & 4 & nAnB & 40 \\
\hline 19 & 66 & $\mathbf{M}$ & 10.6 & 28 & $\mathrm{nAnBnC}$ & 50 \\
\hline 20 & 45 & $\mathrm{~F}$ & uncertain & uncertain & nAnB & 60 \\
\hline 21 & 63 & $\mathbf{F}$ & uncertain & 18.6 & nAnB & 75 \\
\hline 22 & 2 & $\mathbf{M}$ & 3.5 & 10 & nAnB & 91 \\
\hline 23 & 31 & $\mathrm{~F}$ & uncertain & uncertain & nAnB & 100 \\
\hline
\end{tabular}

T-bil : serum total bilirubin on admission

PT : serum prothrombin time on admission virus : B when serum HBs antigen was detected

nAnB when serum IgM HA antibody or HBs antigen was not detected

nAnBnC when IgM HA antibody, HBs antigen or $\mathrm{HCV}$ antibody was not detected HCV antibody could not be assessed other than cases 9 and 19, because the cases died before 1990 .

Course : survival periods from the onset to the death

phosphate buffer. The samples were post-fixed in $2 \%$ osmium tetroxide, dehydrated in ethanol, and embedded in epoxy resin. Ultrathin sections were stained with uranyl acetate and lead citrate after periodic acid-methenamine-silver (PAM) staining, and examined by electron microscopy to identify the cells and fibrogenesis around the proliferated bile ductules.

\section{Results}

Histology of the proliferated bile ductules during the progression of the disease (Table 2)

Proliferation of the bile ductules appeared mainly at the periphery of the necrotic lobules at 9 days following onset on a collapsed background. The ductules were surrounded by spindle-shaped mesenchymal cells, which were thought to be cholangio pericytes (Fig. 1A) ${ }^{11}$. By 37 days, proliferation of the ductules was increased at the periphery of the regenerated nodules on a granulomatous background, and the ductules surrounded by cholangio pericytes 
Table 2. Histological and immunohistochemical findings of the cases

\begin{tabular}{|c|c|c|c|c|c|c|c|}
\hline case & $\begin{array}{l}\text { Hepato } \\
\text { cyte }\end{array}$ & $\begin{array}{c}\text { Bile } \\
\text { ductule }\end{array}$ & Back ground & $\alpha$ SMA & $\begin{array}{c}\text { PCNA } \\
\text { in pericyte }\end{array}$ & TGF $\beta 1$ & TGF $\beta 2$ \\
\hline 1 & - & - & collapsed & background & - & macrophage & - \\
\hline 2 & - & - & collapsed & background & - & macrophage & - \\
\hline 3 & + & + & collapsed & $\begin{array}{l}\text { background } \\
\text { pericyte }\end{array}$ & + & $\begin{array}{l}\text { macrophage } \\
\text { ductule, pericyte }\end{array}$ & ductule \\
\hline 4 & - & - & collapsed & background & - & macrophage & - \\
\hline 5 & - & - & collapsed & background & - & macrophage & - \\
\hline 6 & + & + & collapsed & $\begin{array}{l}\text { background } \\
\text { pericyte }\end{array}$ & + & $\begin{array}{l}\text { macrophage } \\
\text { ductule, pericyte }\end{array}$ & ductule \\
\hline 7 & + & + & collapsed & $\begin{array}{l}\text { background } \\
\text { pericyte }\end{array}$ & + & $\begin{array}{l}\text { macrophage } \\
\text { ductule, pericyte }\end{array}$ & ductule \\
\hline 8 & + & + & collapsed & $\begin{array}{l}\text { background } \\
\text { pericyte }\end{array}$ & + & $\begin{array}{l}\text { macrophage } \\
\text { ductule, pericyte }\end{array}$ & ductule \\
\hline 9 & + & + & granulomatous & $\begin{array}{l}\text { background } \\
\text { pericyte }\end{array}$ & + & $\begin{array}{l}\text { macrophage } \\
\text { ductule, pericyte }\end{array}$ & ductule \\
\hline 10 & + & + & granulomatous & $\begin{array}{l}\text { background } \\
\text { pericyte }\end{array}$ & + & $\begin{array}{l}\text { macrophage } \\
\text { ductule, pericyte }\end{array}$ & ductule \\
\hline 11 & + & + & granulomatous & $\begin{array}{l}\text { background } \\
\text { pericyte }\end{array}$ & + & $\begin{array}{l}\text { macrophage } \\
\text { ductule, pericyte }\end{array}$ & ductule \\
\hline 12 & + & ++ & granulomatous & $\begin{array}{l}\text { background } \\
\text { pericyte }\end{array}$ & + & ductule, pericyte & ductule \\
\hline 13 & + & ++ & granulomatous & $\begin{array}{l}\text { background } \\
\text { pericyte }\end{array}$ & + & ductule, pericyte & ductule \\
\hline 14 & + & ++ & granulomatous & $\begin{array}{l}\text { background } \\
\text { pericyte }\end{array}$ & + & ductule, pericyte & ductule \\
\hline 15 & + & ++ & granulomatous & $\begin{array}{l}\text { background } \\
\text { pericyte }\end{array}$ & + & ductule, pericyte & ductule \\
\hline 16 & + & ++ & granulomatous & $\begin{array}{l}\text { background } \\
\text { pericyte }\end{array}$ & + & ductule, pericyte & ductule \\
\hline 17 & + & ++ & granulomatous & $\begin{array}{l}\text { background } \\
\text { pericyte }\end{array}$ & + & ductule, pericyte & ductule \\
\hline 18 & + & + & fibrotic & $\begin{array}{l}\text { background } \\
\text { pericyte }\end{array}$ & + & ductule, pericyte & ductule \\
\hline 19 & + & + & fibrotic & $\begin{array}{l}\text { background } \\
\text { pericyte }\end{array}$ & + & ductule, pericyte & ductule \\
\hline 20 & + & + & fibrotic & $\begin{array}{l}\text { background } \\
\text { pericyte }\end{array}$ & + & ductule, pericyte & ductule \\
\hline 21 & + & + & fibrotic & $\begin{array}{l}\text { background } \\
\text { pericyte }\end{array}$ & + & ductule, pericyte & ductule \\
\hline 22 & + & + & fibrotic & $\begin{array}{l}\text { background } \\
\text { pericyte }\end{array}$ & + & ductule, pericyte & ductule \\
\hline 23 & + & + & fibrotic & $\begin{array}{l}\text { background } \\
\text { pericyte }\end{array}$ & + & ductule, pericyte & ductule \\
\hline
\end{tabular}

Hepatocyte : - when hepatocytic regeneration is not seen

+ when hepaticytic regeneration is seen

Bile ductule : - when bile ductular proliferation is not seen

+ when bile ductular proliferation is mild degree

++ when bile ductular proliferation is greater degree 


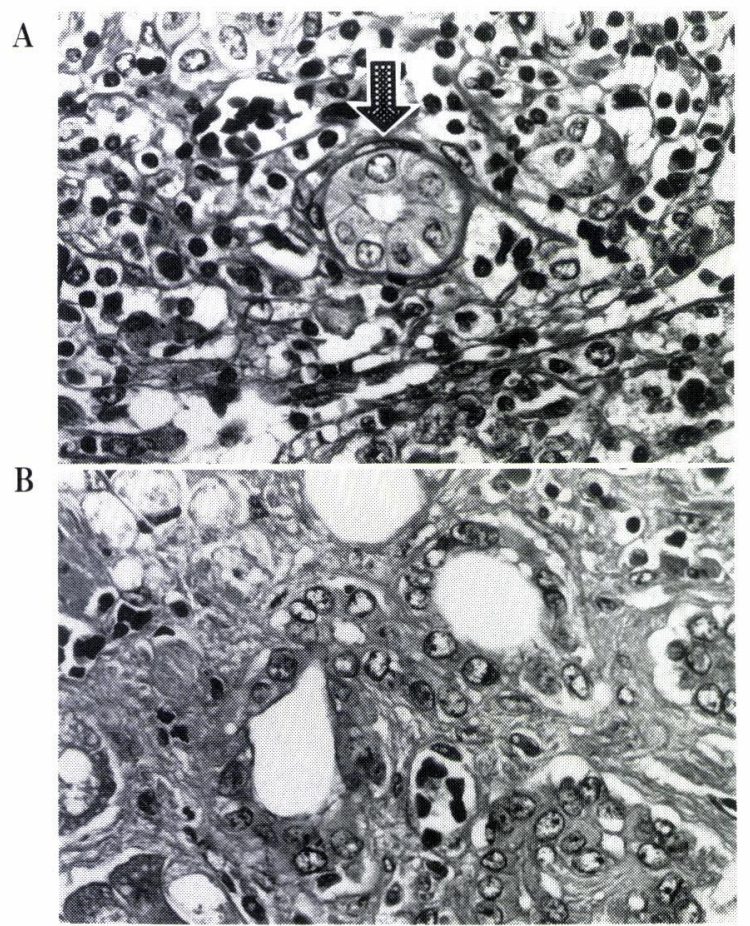

Fig. 1. Photomicrographs of the proliferated bile ductules (A) Small numbers of the ductules, which were surrounded by cholangio pericytes (arrow), were seen at the periphery of the necrotic lobules 9 days following onset, hematoxylin and eosin, magnification $\times 200)$. (B) The numbers of ductules was increased, and periductular fibrosis was more severe for a fibrous background ( 75 days following onset, hematoxylin and eosin, magnification $\times 200$ )

showed an accompanying periductular fibrosis. By 75 days following onset, periductular fibrosis had become more severe on a dense fibrous background (Fig. 1B). No cholangio pericytes were observed around the bile ducts in the control samples (normal hepatic specimens).

\section{Immunohistochemistry (Table 2)}

Alpha smooth muscle actin ( $\alpha$ SMA)

The cholangio pericytes showed cytoplasmic immunostaining for $\alpha$ SMA from the onset of the hepatitis (Fig. 2A). In contrast, there were no $\alpha$ SMA positive cells in Glissonís area other than in the vascular smooth muscle. The spindle shaped mesenchymal cells in the collapsed background at 9 days, and both fibrous background itself and spindle shaped mesenchymal cells by 75 days were also stained positive for a SMA (Fig. 2B). Immunohistochemical double staining revealed that the nucleus of the $\alpha$ SMA positive cholangio pericytes was occasionally (less than $5 \%$ ) also stained positive for PCNA (Fig. 2C). Control tissues showed no $\alpha$ SMA postive cells other than in the vessel smooth muscle. 


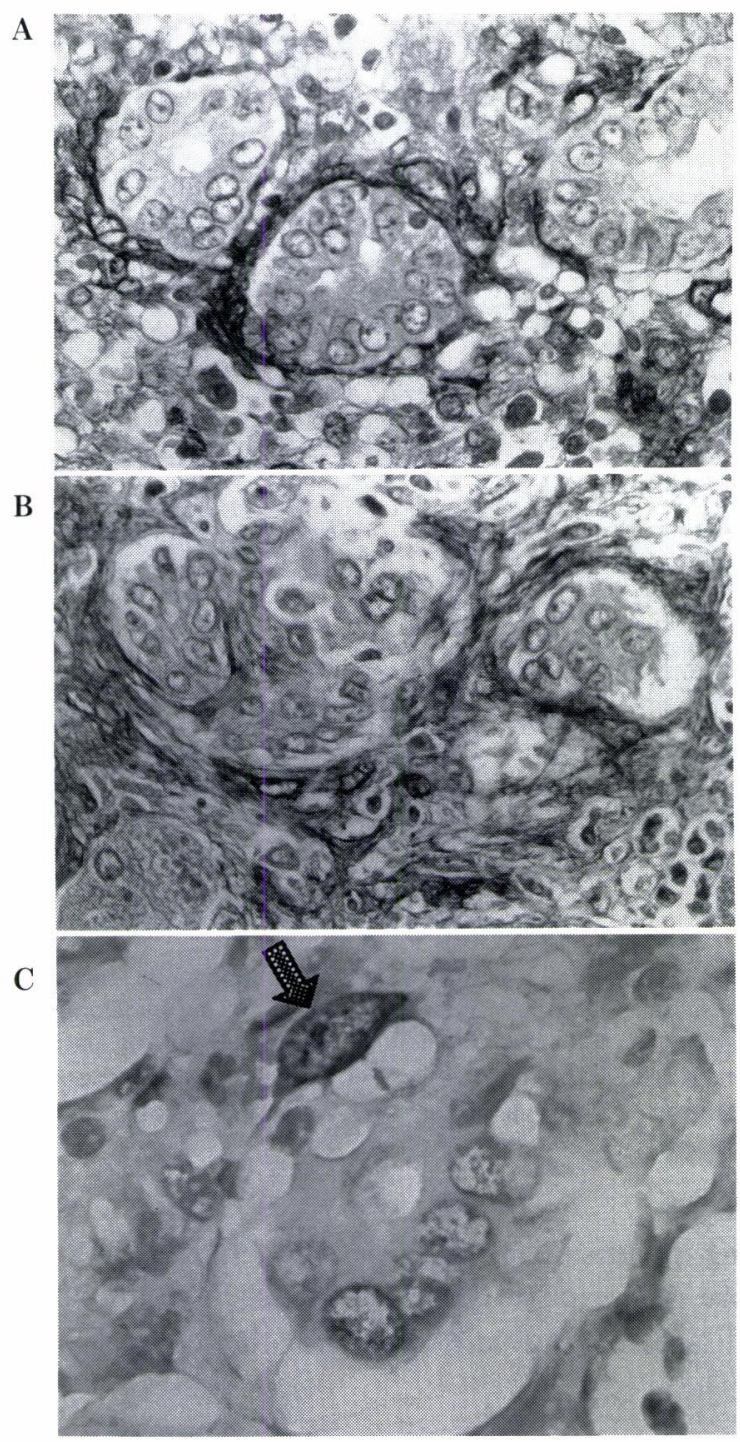

Fig. 2. Immunohistochemistry for $\alpha$ smooth muscle actin (A) The cytoplasm of cholangio pericytes was stained positive. ( 9 days following onset, LSAB method,magnification $\times 200)($ B $)$ Fibrous background and cholangio pericytes were also immunopositive ( 75 days following onset, LSAB method, magnification $\times 200$ ). (C) Nucleus of the cholangio pericytes (arrow) was stained brown with the proliferating cell nuclear antigen, and the cytoplasm showed red staining for $\alpha$ smooth muscle actin (60 days following onset, double immunostaining, magnification $\times 500$ )

The cytoplasm of proliferated ductular epithelia and ordinal interlobular bile duct epithelia showed diffuse immunopositive staining for TGF $\beta 1$ from disease onset. Macrophages in the necrotic background were diffusely positive, and a few cholangio pericytes were positive for TGF $\beta 1$ by 9 days following onset, but most lymphocytes were negative at all stages of the disease (Fig. 3A). By 18 days the number of TGF $\beta 1$ positive macrophages was decreased, and TGF $\beta 1$ positive cholangio pericytes were increased (Fig. 

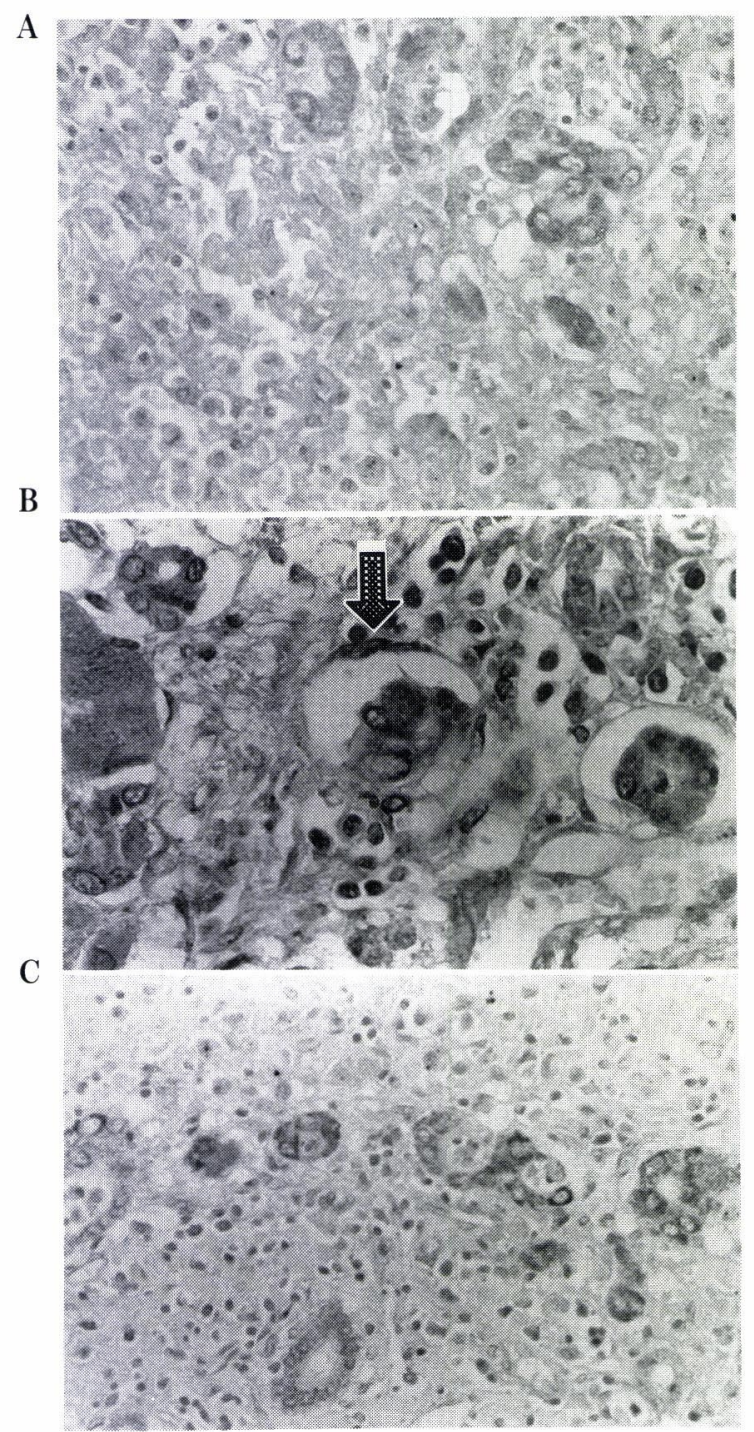

Fig. 3. Immunohistochemistry for transforming growth factor $\beta$ (TGF $\beta$ )

(A) The cytoplasm of the ductular epithelia and macrophages showed staining for TGF $\beta 1$ ( 9 days following onset, LSAB method, magnification $\times 100)$. (B) The cytoplasm of the ductular epithelia and cholangio pericytes (arrow) were positive for TGF $\beta 1$ (18 days following onset, LSAB method, magnification $\times 200$ ). (C) Approximately half of the ductular epithelia cells but no macrophages were positive for TGF $\beta 2$ ( 9 days following onset, LSAB method, magnification $\times 100$ )

3B). Control bile duct epithelia showed no positive staining for TGF $\beta 1$.

\section{Transforming growth factor beta2 (TGF $\beta 2)$}

Approximately half of the proliferated ductular epithelia and ordinal interlobular bile duct epithelia showed positive cytoplasmic staining for TGF $\beta 2$ from disease onset, although most macrophages, lymphocytes and cholangio pericytes in the background were negative throughout the course of the disease (Fig. 3C). No TGF $\beta 2$ immunostaining was seen in 


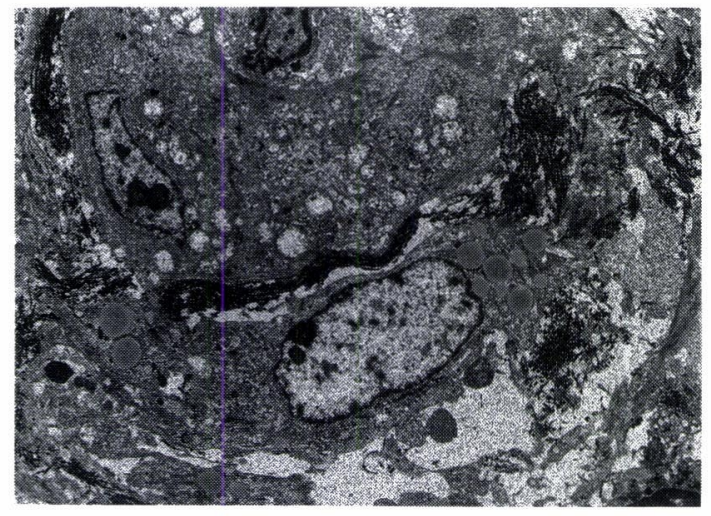

Fig. 4. Electron microscopy of the cholangio pericytes Cells containing fatty droplets in the cytoplasm surrounded the ductules, producing PAM positive collagen fibers around the cells (10 days following onset, PAM staining, magnification $\times 2000)$

the normal controls.

\section{Electron microscopic findings of the cells and fibrosis around the ductules}

By electron microscopy, cholangio pericytes containing fatty droplets in the cytoplasm were seen surrounding the proliferated bile ductules, producing PAM positive collagen fibers around the cells (Fig. 4). PAM positive collagen fibers were scattered by 37 days from the onset, but by 75 days they had circumscribed the ductules.

\section{Discussion}

In many hepatic diseases, periductular fibrosis is accompanied by proliferation of the bile ductules, which is one of the mechanisms leading to hepatic fibrosis ${ }^{12-14)}$. Fulminant hepatitis is characterized by proliferated bile ductules derived from hepatic cells appearing at the periphery of necrotic and/or regenerated lobules ${ }^{15)}$, with subsequent fibrosis of the ductules occuring during the course of the disease. The mechanism by which this periductular fibrosis develops remains unclear, although most postnecrotic hepatic fibrosis can be attributed to the fat-storing cells in and around the necrotic hepatic lobules ${ }^{3)}$. Our study of the proliferated bile ductules in fulminant hepatitis revealed cholangio pericytes ${ }^{11}$ surrounding the ductules. These are the spindle shaped mesenchymal cells circumscribing the ductules, from the earliest phase of the disease, which show positive immunoreactivity for both cytoplasmic $\alpha$ SMA and nuclear PCNA. Electron microscopy confirmed that the cholangio pericytes contained fatty droplets in their cytoplasm. These immunohistochemical and electron microscopic findings suggested that cholangio pericytes were the fat-storing cells responsible for the proliferating potential. Moreover, the extent of periductular fibrosis was correlated with the time course of the disease, and electron microscopy also revealed that fat-storing cells were producing collagen fibers around the ductules. Our results indicate that fat-storing cells are central not only in postnecrotic hepatic fibrosis, but also in periductular fibrosis occurring in the course of fulminant hepatitis.

The proliferation of fat-storing cells can be promoted by fibrogenic growth factors such as TGF $\beta$ and PDGF released by inflammatory cells ${ }^{6,7)}$ and by the fat-storing cell itself via 
an autocrine/paracrine mechanism ${ }^{16,17)}$. In addition, recent studies reported the expression of fibrogenic growth factors in the epithelia of bile ducts and proliferated ductules in hepatic diseases $^{8-10)}$. TGF $\beta 1$ and TGF $\beta 2$ are differentially expressed in human fibrotic liver but not in normal liver ${ }^{5,10)}$, and functional differences exist between TGF $\beta 1$ and TGF $\beta 2^{5)}$. TGF $\beta 1$ is expressed as a general response to hepatic injury, and plays an important role in the process of hepatic fibrosis ${ }^{5,17-19)}$. On the other hand, TGF $\beta 2$ expression is a specific property of the bile duct and ductular epithelia, and plays a specialized role in the process of periductular fibrosis ${ }^{5)}$. In our study of fulminant hepatitis, ductular epithelia showed positive immunoreactivity for both TGF $\beta 1$ and TGF $\beta 2$ from the early phase of the disease through to the latter stages. In contrast, macrophages were positive for TGF $\beta 1$ only in the early phase of the disease and fat-storing cells were positive only in the latter phase. Our results indicate that there are spatial and functional differences between TGF $\beta 1$ and TGF $\beta 2$, and also implicate TGF $\beta 1$ expression in the fat-storing cell itself as significant for further fibrogenesis ${ }^{16)}$. Based on the findings presented here, a model can be proposed for the fibrogenic process surrounding the bile ductules in fulminant hepatitis. Firstly, bile ductular proliferation appears at the periphery of the lobules as a reaction to massive hepatic necrosis. Secondly, increased TGF $\beta 1$ and TGF $\beta 2$ expression in the ductular epithelia and increased TGF $\beta 1$ expression in the macrophages of the necrotic background promote the aggregation and fibrogenesis of fat-storing cells in the periductular areas. Finally, an increased TGF $\beta 1$ expression in the fat-storing cell itself additionally promotes an ongoing periductular fibrosis.

Proliferated bile ductules act to enhance the bile drainage from hepatic cells to interlobular bile ducts ${ }^{15,20)}$, and as we previously reported, excessive ductules are deleted via apoptosis during reconstruction of the intrahepatic biliary system ${ }^{21,22}$. Hepatic tissue from patients with fulminant hepatitis in recovery phase with favorable prognosis show no remarkable bile ductular proliferation or hepatic fibrosis ${ }^{23,24)}$. Considering then the reversible nature of the bile ductule proliferation, we propose two possibilities to prevent hepatic fibrosis based on the ductules in fulminant hepatitis. One is to inhibit the proliferation of bile ductules, and the other is to pharmacologically limit TGF $\beta$ expression ${ }^{25,26)}$.

In conclusion, this study supports the theory that postnecrotic hepatic fibrosis is carried out by fat-storing cells, even in periductular fibrosis, although via a different fibrogenic growth factor.

\section{Acknowledgement}

The authors thank Ms. Akiko Arakawa and Ms. Tomoko Nagai for their excellent technical assistance.

\section{References}

1) Hautekeete ML and Geerts A: The hepatic stellate (Ito) cell: its role in human liver disease. Virchows Arch 430 : 195-207 (1997)

2) Gulubova MV, Stoyanov HD, Julianov AE, Vasilev IV, Stoyanova II and Hadjipetkov PB: Immunohistochemical detection of collagen type III and IV in relation with transformation of Ito cells in liver sinusoids of patients with reactive biliary hepatitis. Acta Histochem 101 : 213-228 (1999)

3) Enzan H, Himeno H, Iwamura S, Saibara T, Onishi S, Yamamoto Y, Miyazaki E and Hara H: Sequential changes in human Ito cells and their relation to postnecrotic liver fibrosis in massive and submassive hepatic necrosis. Virchows Arch 426 : 95-101 (1995)

4) Bissell DM, Friedman SL, Maher JJ and Roll FJ : Connective tissue biology and hepatic fibrosis: report of a 
conference. Hepatology 11 : 488-498 (1990)

5) Milani S, Herbst H, Schuppan D, Stein H and Surrenti C: Transforming growth factors b1 and b2 are differentially expressed in fibrotic liver disease. Am J Pathol 139 : 1221-1229 (1991)

6) Gressner AM and Bachem MG : Cellular sources of noncollagenous matrix proteins: role of fat storing cells in fibrogenesis. Semin Liver Dis $10: 30-46$ (1990)

7) Friedman SL: Cellular sources of collagen and regulation of collagen production in liver. Semin Liver Dis 10 : 20-29 (1990)

8) Malizia G, Brunt EM, Peters MG, Rizzo A, Broekelmann TJ and McDonald JA: Growth factor and procollagen type I gene expression in human liver disease. Gastroenterology $108: 145-156$ (1995)

9) Pinzani M, Milani S, Herbst H, DeFranco R, Grappone C, Gentilini A, Caligiuri A, Pellegrini G, Ngo DV, Romanelli RG and Gentilini P: Expression of platelet-derived growth factor and its receptors in normal human liver and during active hepatic fibrosis. Am J Pathol 148 : 785-800 (1996)

10) Ahmed AFKU, Ohtani H, Nio M, Funaki N, Iwami D, Kumagai S, Sato E, Nagura $H$ and Ohi R: In situ expression of fibrogenic growth factors and their receptors in biliary atresia: comparison between early and late stages. J Pathol 192 : 73-80 (2000)

11) Kunimura T, Ooike N, Sasajima Y, Inagaki T and Morohoshi T : Periductal fibrosis of biliary atresia. Is it not caused by fat-storing cells? Am J Gastroenterol 96 : 924-926 (2001)

12) Hutterer F, Rubin E, Singer EJ and Popper H : Quantitative relation of cell proliferation and fibrogenesis in the liver. Cancer Res $21: 206-214$ (1961)

13) Popper H and Udenfriend S : Hepatic fibrosis. Am J Med 49 : 707-721 (1970)

14) Schaffner F and Popper $\mathrm{H}:$ : Electron microscopic studies of normal and proliferated bile ductules. Am J Pathol 38 : 393-410 (1961)

15) Thung SN : The development of proliferating ductular structures in liver disease. Arch Pathol Lab Med 114 : 407-411 (1990)

16) Van Obberghen-Schilling E, Roche NS, Flanders KC, Sporn MB and Roberts AB : Transforming growth factor beta 1 positively regulates its own expression in normal and transformed cells. $J$ Biol Chem 263 : 7741-7746 (1988)

17) Braun L, Mead JE, Panzica M, Mikumo R, Bell GI and Fausto N: Transforming growth factor $\beta$ mRNA increase during liver regeneration: A possible paracrine mechanisms of growth regulation. Proc Natl Acad Sci USA 85 : 1539-1543 (1988)

18) Fausto $\mathrm{N}$ and Mead JE: Regulation of liver growth. Protooncogenes and transforming growth factors. Lab Invest $60: 4-13$ (1989)

19) Carr BI, Hayashi I, Branum EL and Moses HL: Inhibition of DNA synthesis in rat hepatocytes by platelet-derived type $\beta$ transforming growth factor. Cancer Res 46 : 4665-4671 (1986)

20) Uchida $T$ and Peters RL: The nature and origin of proliferated bile ductules in alcoholic liver disease. Am $J$ Clin Pathol 79 : 326-333 (1983)

21) Kunimura T, Ooike N, Sasajima $Y$, Ishikawa $Y$, Inagaki $T$ and Morohoshi $T$ : Subsequent loss of the proliferated bile ductules in fulminant hepatitis in childhood. Isn't it caused by apoptosis? Am J Gastroenterol $96: 1299-1300(2001)$

22) Bhanthal PS and Gall JAM : Deletion of hyperplastic biliary epithelial cells by apoptosis following removal of the proliferative stimulus. Liver $5: 311-325$ (1985)

23) Karvountzis GG, Redeker AG and Peters RL: Long term follow-up studies of patients surviving fulminant viral hepatitis. Gastroenterology $67: 870-877$ (1974)

24) Horney JT and Galambos JT: The liver during and after fulminant hepatitis. Gastroenterology 73 : 639-645 (1977)

25) Nakamura T, Sakata R, Ueno T, Sata $M$ and Ueno $\mathbf{H}$ : Inhibition of transforming growth factor beta prevents progression of liver fibrosis and enhances hepatocyte regeneration in dimethylnitrosamine-treated rats. Hepatology. 32 : 247-255 (2000)

26) George J, Roulot D, Koteliansky VE and Bissell DM: In vivo inhibition of rat stellate cell activation by soluble transforming growth factor beta type II receptor: a potential new therapy for hepatic fibrosis. Proc Natl Acad Sci USA 96 : 12719-12724 (1999)

[Received May 25, 2001 : Accepted June 18, 2001] 